\title{
Stability-Indicating Stabilization of Rice Bran Food Value by Heat Treatment
}

\author{
Fahmida Nusrat MS ${ }^{1}$, Md. Alauddin PhD ${ }^{2}$, Tania Rahman PhD ${ }^{1}$, Mohammad Ali Zinnah MS ${ }^{1}$, \\ Tanzir Ahmed Khan MS ${ }^{3}$ and M Zakir Hossain Howlader PhD ${ }^{1^{*}}$ \\ ${ }^{1}$ University of Dhaka, Department of Biochemistry and Molecular Biology, Dhaka-1000, Bangladesh \\ ${ }^{2}$ Jessore University of Science and Technology, Department of Nutrition and Food Technology, Jessore-7408, Bangladesh
}

${ }^{3}$ Bangladesh Council of Scientific and Industrial Research (BCSIR), Dhaka, Bangladesh

Received: 10 January, 2019; Accepted: 25 January, 2019; Published: 5 February, 2019

*Corresponding author: M Zakir Hossain Howlader, Department of Biochemistry and Molecular Biology University of Dhaka, Dhaka-1000, Bangladesh; E-mail: hhzakir@yahoo.com

\begin{abstract}
Rice bran (RB) is a natural source of nutrients that help to reduce oxidative-stress related diseases. But stability-indicating stabilization of RBfood values are still challenging due to degradation of excessive lipid contents eventually produces off-flavors and odors. This study aims stability-indicating stabilization of RB food value by heating such as autoclave $\left(120^{\circ} \mathrm{C}, 180 \mathrm{~min}\right.$ by HICLAVETM,HVE-50instrument), roasting $\left(150^{\circ} \mathrm{C}, 10 \mathrm{~min}\right.$ by Heating oven), steaming $\left(120^{\circ} \mathrm{C}, 120 \mathrm{~min}\right.$ by Domestic cooking steamer) and microwave (1500C, 3min by Domestic microwave oven, WALTON, Bangladesh)followed by stability testing at $-20^{\circ} \mathrm{C}$ and $4^{\circ} \mathrm{C}$ for 16 weeks. We measured the proximate composition, phenolic content, tannic acid, flavonoid, antioxidant activity, IC50 value, oxidative stability, peroxide and acid value, oil extraction before and after aforementioned treatment of RB. It was found that roasting and microwave treatment significantly $(\mathrm{P}<0.05)$ increased the stability of macronutrients as well as corresponding oil extraction yield. Moreover, roasting and microwave treatment significantly $(P<0.05)$ increased the stability of total tannin, flavonoid and antioxidant activity. Though roasting technique decreased the stability of monounsaturated fatty acid but increased gamma-oryzanol content and poly unsaturated fatty acid. In conclusion, the technique of roasting and microwave heating are more efficient for stability-indicating stabilization of RB food value.
\end{abstract}

Keywords: Ricebran; macronutrients; stabilization; gammaoryzanol; antioxidant:

\section{Introduction}

Bangladesh is one of the largest rice production country and approximately 40 million metric ton rice production per year accounts 3 million metric ton crude rice bran in Bangladesh but most of them are used as animal feed or waste material [1]. Rice varieties in particular region of Bangladesh have been explored with their composition like protein $(7.04 \%)$, fat $(0.37 \%)$, crude fibre $(0.26 \%)$ and ash $(0.58 \%)$ in parboiled milled rice [2]. Rice bran oil from different rice varieties in Bangladesh (BR-5, BR10, BRRI-28, BRRI-39 from different automatic rice mills) have been examined to their constituents lipid, fatty acid and glyceride [3]. Moreover functional properties of aromatic rice varieties showed exciting composition such as moisture (11.25-15.13\%), protein (3.23-6.21\%), fat (0.68- 1.45\%) and ash (0.88-1.46\%) [4]. Recent study showed that cold treated rice bran (BRRI-28) is being useful in many food applications such as food supplement and edible oil extraction [5]. Additionally rice bran is the excellent source of valuable bioactive compounds such as dietary fiber, vitamins, and antioxidants [6]. Recently rice bran is used as a food ingredient to add value as a functional food because it contains a large amount of nutrients and antioxidants including phenolic acids, flavonoids, gamma oryzanol,etc. Compared to other portion of whole grain, rice bran containshighest amount of protein, crude fat, crude ash, crude fiber, total dietary fiber, phenolics, gamma-oryzanol, vitamin-E, anthocyanin pigment and some essential minerals ( $\mathrm{Fe}, \mathrm{Zn}$ ). Unfortunately, the bran cannot be preserved as it is for an extended period due to hydrolytic and oxidative rancidity of the of its oil content (12-19\%). When bran layers are removed from the endosperm, the individual cells are disrupted, and the rice bran lipids come into contact with highly reactive lipases. These enzymes are both endogenous to the bran and of microbial origin and initiate hydrolytic deterioration of kernel oil [7]. Most enzymes are effective in aqueous systems in which both the enzyme and substrate are soluble. Therefore, it must be stabilized immediately upon production due primarily to the presence of a lipase, an enzyme that rapidly hydrolyzes oil to free fatty acids (FFA) and glycerol, resulting in the drastic quality reduction of the RB. The enzymes like lipoxygenase and peroxidase also play a fundamental role for oxidative rancidity (the oxidation of double bond present in fatty acids). The primary reason for the present failure of using rice bran for food purpose is the time period between its production and utilization. If the oil is not extracted immediately from bran, it will be hydrolyzed into free fatty acids (FFA) and glycerol by active lipase enzymes. The rate of oil degradation and FFA formation can be very high (about 5-7\% per day and upto $70 \%$ in a month) under favorable condition [8]. Oxidation of FFA leads to the production of various off-odor compounds, such as aldehydes and ketones. Bran oil with an excess of 10\% FFA is unfit for human consumption, and due to high refining loss, bran with more than 5\% FFA will be 
unprofitable for edible oil extraction [9].In the case of lipase, the substrate is insoluble in water, and the enzyme is active at the oil-water interface [10]. While many rice growing countries are suffering from a lack of edible oils and protein products, rice bran oil extraction and protein separation in these areas are not adequately applied because few effective bran stabilizing procedures are adaptable to commercial production. Several stabilization prepositions has been employed and Most heat treatments (steam retorting, extrusion cooking) are being extensively used for rice bran stabilization.

The primary means for satbility-indicating rice bran stabilization include deactivating the enzymes through heat treatment through ahot air, oven or microwave heating [11], steaming [12],extrusion[13], refrigeration and pH lowering [14]. Microwaves, infrared radiations and ohmic heating have offered an alternative energy source for stabilization of rice bran. But compared with other heat treatments,microwave heating is efficient, economically superior, shorter in processing time and has little effect on the nutritional valueof bran. The advantageous effect of microwave heating in stabilizing the rice bran has been confirmed by many researchers [15-18]. Considering this background, the present study was proposed to stabilize the rice bran with the following objectives: compare different heat treatment methods and analysis their functional composition before and after heat treatment with preserved at $-20^{\circ} \mathrm{C}$ and $4^{\circ} \mathrm{C}$ for 16 weeks.

\section{Methods and Materials}

\section{Sample preparation}

The study was conducted with a farmer-popular rice bran sample. The rice variety BR11 is the source of study sample that was collected from Bangladesh Rice Research Institute (BRRI). The sample was treated with four different stabilization methods to stabilize rice bran. The rice bran was divided into two major groups one for preserve at $-20^{\circ} \mathrm{C}$ and another store at $4^{\circ} \mathrm{C}$, and then each group were divided into four sub groups. One portion from each major group was kept as control (untreated). Rest of the sub groups were treated with different heating methods such as autoclave, roasting, steaming and microwave heating. The untreated and two major groups were kept in storage for 4 months ( 16 weeks) at $-20^{\circ} \mathrm{C}$ and $4^{\circ} \mathrm{C}$. There were total 10 sets of samples. The heat treatment methods are summarized in Table 1:

\begin{tabular}{|c|c|c|}
\hline \multicolumn{2}{|c|}{ Table 1: Rice bran stabilization by different heat treatment methods } \\
\hline Heating methods & $\begin{array}{c}\text { Heating } \\
\text { conditions }\end{array}$ & Instruments \\
\hline Autoclave & $120^{\circ} \mathrm{C}, 180$ minute & HICLAVETM,HVE-50 \\
\hline Roasting & $150^{\circ} \mathrm{C}, 10$ minute & Heating oven \\
\hline Steaming & $120^{\circ} \mathrm{C}, 60$ minute & Domestic cooking steamer \\
\hline Microwave heating & $\begin{array}{c}150^{\circ} \mathrm{C}, 3 \text { minute } \\
\text { Power } 800 \mathrm{w}, \\
\text { frequency } 2450\end{array}$ & $\begin{array}{c}\text { Domestic microwave } \\
\text { oven(WALTON, } \\
\text { BHz }\end{array}$ \\
\hline \multirow{2}{*}{\begin{tabular}{c} 
Bangladesh) \\
\hline
\end{tabular}}
\end{tabular}

\section{Oil extraction from rice bran}

Soxhlet extraction was followed to extract oils from the corresponding rice bran using petroleum ether as a solvent. 13$16 \mathrm{~g}$ of sample was taken into a thimble. Approximately $250 \mathrm{~mL}$ petroleum ether was poured into pre-weighted round joint flask with boiling chips. Soxhlet apparatus was set for extraction to 8 hours. After extraction, the flask was kept in the oven to evaporate the solvent. Then, the flask was left to cool down and reweighted after cooled down.

\section{Proximate composition of rice bran}

Moisture, fat, protein, carbohydrate, ash and crude fiber was measured according to published methods [19-21].

\section{Determination of total phenolic content, tannin content, flavonoid content, antioxidant activity and DPPH radical scavenging activity of rice bran}

The Folin-ciocalteu Phenol reagent method [22] was used to determine the total phenolic contents as mg of Gallic acid equivalent per gram sample using the equation obtained from a standard gallic acid calibration curve; $\mathrm{Y}=0.005 \mathrm{X}+0.00$, $\mathrm{R} 2=$ 0.998 . The tannins were determined using the same method. Total tannin content was determined as mg of tannic acid equivalent per gram sample using the equation obtained from a standard tannic acid calibration curve; $\mathrm{Y}=0.006 \mathrm{X}+0.021, \mathrm{R} 2=0.989$. The results of tannins were expressed in terms of tannic acid in $\mathrm{mg} / \mathrm{g}$ of dry extract. The flavonoid content was determined according to Zhishen et al., 1999 method [23]. Total flavonoid content was determined as $\mathrm{mg}$ of equivalent per gram sample using the equation $\mathrm{Y}=0.009 \mathrm{X}-0.008, \mathrm{R} 2=0.998$ for calibration curve. The results of flavonoids are expressed in terms of Quercetin equivalent (mg per $\mathrm{g}$ of dry mass), which is a common reference compound.

\section{Measurement of antioxidant activity and DPPH radical scavenging activity}

The total antioxidant activity of the extract was evaluated by using Prieto et al., 1999 method [24]. The phosphomolybdenum assay method which is based on the reduction of Mo (VI) to Mo (V) by the extract and subsequent formation of a green phosphate-Mo (V) complex in acidic condition. The antioxidant activity was expressed as the number of gram equivalents of ascorbic acid. Antioxidant activity was determined as mg of AAE equivalent per gram using the equation obtained from a standard AAE calibration curve $Y=0.007 X-0.038, R 2=0.990$.

The percentage of DPPH radical-scavenging activity of each plant extract was calculated as: DPPH radical-scavenging activity

$$
(\% \mathrm{I}),=\frac{\mathbf{A} 0-\mathbf{A}}{\mathbf{A} 0} \times 100
$$

Where, $\mathrm{A} 0=$ absorbance of the control solution (containing all reagents except plant extracts); $\mathrm{A}=$ absorbance of the DPPH solution containing plant extract. The DPPH radical-scavenging activity (\%) was plotted against the plant extract concentration to determine the concentration of extract necessary to decrease 
DPPH radical-scavenging by 50\% (called IC50). Ascorbic acid was used as positive control standard according to the published method [25-26].

\section{Measurement of oxidative stability, peroxide value and acid value}

Oxidative stability of rice bran oils (extracted from rice bran) was determined according to AOCS Cd 12b-92 [27-28]. MetrohmRancimat model 743 (Metrohm CH-9101, Herisau, Switzerland) capable of operating over a temperature range of $110 \mathrm{o} C$ was used. A stream of air was bubbled into oil samples ( $2.5 \mathrm{~g}$ to $3.0 \mathrm{~g}$ ) contained in a reaction vessel placed in an electric heating block. The effluent air that contained volatile organic acids from the oil sample was collected in a measuring vessel containing distilled water $(60 \mathrm{~mL})$. The conductivity of the water as oxidation proceeded was measured automatically. Filtered, cleaned, dried air was allowed to bubble through the hot oil at a rate of $20 \mathrm{~L} / \mathrm{h}$ The oxidative stability of the samples was automatically recorded at $110 \mathrm{o}$ C. In each time eight oil samples were accommodated in the equipment and analyzed simultaneously. The oil samples for all determinations were randomized to determine their position in the heating block.

The peroxide value was done by titration method [29]. Oil sample is dissolved with solvent mixture containing glacial acetic acid and chloroform (1.5:1.0). Saturated aqueous potassium iodide solution is added that supplies free iodide ion. Then the reaction is allowed to occur in a dark place to hurdle the light reaction with potassium iodide. The amount of free iodine was determined by titrating against $0.001 \mathrm{M}$ sodium thiosulphate. The titration volume and sample weight determine the peroxide value.

The acid value is defined as the number of milligrams of potassium hydroxide required to neutralize the free fatty acids present in one gram of fat. It is a relative measure of rancidity as free fatty acids are normally formed during decomposition of oil glycerides. The value is also expressed as per cent of free fatty acids calculated as oleic acid. The acid value is determined by directly titrating the oil/fat in an alcoholic medium against standard potassium hydroxide/sodium hydroxide solution.

\section{Quantification of gamma oryzanol content by High performance liquid chromatography (HPLC)}

Gamma oryzanol content was quantified by High-Performance Liquid Chromatography (HPLC) following methods proposed by Tuncel\& Yilmaz2011 [30]. Standard gamma oryzanol was acquired from Sigma-Aldrich located at St. Louis, MO, USA. Dichloromethane, n-Hexane, isopropanol, acetonitrile, methanol, and acetic acid were obtained from Merck GmbH located in Germany. All solvents maintained HPLC grade. Samples were prepared using Isopropanol and n-Hexane. The mobile phase consisted of methanol, acetonitrile, dichloromethane and acetic acid (50:44:3:3, v/v).

\section{HPLC system}

Chromatographic analyses were performed using a Thermo Scientific Dionex UltiMate

3000 Rapid Separation LC (RSLC) systems (Thermo Fisher Scientific Inc., MA, USA), which was coupled to a quaternary rapid separation pump (LPG-3400RS), Ultimate 3000RS autosampler (WPS-3000) and rapid separation diode array detector (DAD-3000RS). An Acclaim ${ }^{\circledR}$ Polar Advantage II (PAII) C18 (4.6 x $250 \mathrm{~mm} ; 5 \mu \mathrm{m} ; 120 \mathrm{oA}$ ) column (Dionix, USA) controlled at $40 \mathrm{oC}$ using a temperature controlled column compartment (TCC3000) was used to separate Gamma oryzanol. DionixChromeleon software (Version 6.80 RS 10) was utilized for data acquisition, peak integration, and calibration.

\section{Chromatographic conditions}

The flow rate was $1 \mathrm{ml} / \mathrm{min}$ (isocratic), and the injection volume was $5 \mu$ l.UV detection wavelength was set at $315 \mathrm{~nm}$. Each sample was allocated a runtime of 35 minute.

\section{Peak characterization and quantification}

The ferulates are expressed as the percentages of gamma oryzanol and are calculated based on their areas.

\section{Fatty acid composition analysis by Gas chromatography (GC) from rice bran oils}

Fatty acid composition analysis was conducted using Gas Chromatogram (GC) which was fitted with Flame Ionization Detector (GC-FID), Model 14B (Shimadzu, Japan) and was loaded with software Class GC-10(version2.0).

\section{Statistical Analysis}

Statistical analysis was performed using graph Pad Prism version 5 and Microsoft Excel 2013. Statistical tests ANOVA and two tailed t-test were performed. The level of significance was assumed for differences with $\mathrm{P}<0.05$.

\section{Result}

Proximate composition of rice bran samples before and after treatments with stability for 16 weeks

The proximate composition of rice bran sample was analyzed before treatment. After heat and stability treatment we measured again the proximate composition of rice bran sample to compare the effect of heat on stability. The moisture content in all treatments groups exceptsteam treatmentis significantly different $(\mathrm{P}<0.05)$ compare to untreated. Among the treated groups the roasting and microwave treatment significantly decreased the moisture content compare to untreated and autoclave. For fat content, the differences are not significant $(\mathrm{P}=0.173)$ but have trend to decrease by steaming and increase by roasting. For protein content, the differences are significant for all the samples $(\mathrm{P}<0.05)$ except autoclave treated sample. The protein content was decreased by roasting and microwave whereas increased by steaming treatment. There were not significant differences 
$(\mathrm{P}>0.05)$ in ash content. There were significantly $(\mathrm{P}<0.05)$ increased for crude fiber content in roasting, steaming and microwave treatment compare to untreated. The carbohydrate content significant $(\mathrm{P}<0.05)$ increased for roasting, steaming and microwave treated samples. Data are showed in Table 2.

Table 2: Proximate composition of rice bran samples before and after treatments. Data is presented as mean value \pm standard error of mean (SEM). ${ }^{*}$ P value $<0.05$ was considered statistically significant compared to untreated sample.

\begin{tabular}{|c|c|c|c|c|c|c|}
\hline Sample name & Moisture & Fat & Protein & Ash & Crude fiber & Carbohydrate \\
\hline Untreated & $10.53 \pm 0.18$ & $18.97 \pm 0.06$ & $15.67 \pm 0.01$ & $8.27 \pm 0.01$ & $6.64 \pm 0.02$ & $46.56 \pm 0.01$ \\
\hline Autoclave & $12.25 \pm 0.09^{*}$ & $18.98 \pm 0.55$ & $15.75 \pm 0.01$ & $7.38 \pm 0.27$ & $7.61 \pm 0.03$ & $45.63 \pm 0.01$ \\
\hline Roasting & $1.69 \pm 0.06^{*}$ & $22.34 \pm 0.55$ & $13.95 \pm 0.04^{*}$ & $8.80 \pm 0.02$ & $7.95 \pm 0.08^{*}$ & $53.21 \pm 0.01^{*}$ \\
\hline Steaming & $9.97 \pm 0.18$ & $10.31 \pm 4.0$ & $17.45 \pm 0.01^{*}$ & $7.41 \pm 0.01$ & $13.69 \pm 0.30^{*}$ & $54.86 \pm 0.01^{*}$ \\
\hline Microwave & $4.89 \pm 0.05^{*}$ & $21.07 \pm 0.61$ & $13.98 \pm 0.01^{*}$ & $6.59 \pm 0.89$ & $7.96 \pm 0.01^{*}$ & $53.47 \pm 0.01^{*}$ \\
\hline
\end{tabular}

Determination of total phenolic, tannin, flavonoid, antioxidant activity and DPPH radical scavenging activity of rice bran.

The bioactive compounds and antioxidant activity of untreated and after treatment with stability at $-20^{\circ} \mathrm{C}$ and $4^{\circ} \mathrm{C}$ for 16 weeks were analyzed. The table 3 showed that the roasting and microwave treatment significantly $(\mathrm{P}<0.05)$ increased the phenolic content $(125.73 \pm 0.30 \mathrm{mg} \mathrm{GAE} / \mathrm{g}$ of dry extract and $84.53 \pm 0.87 \mathrm{mg} \mathrm{GAE} / \mathrm{g}$ of dry extract respectively)compared to untreated sample at $-20^{\circ} \mathrm{C}$ for 16 weeks. Total tannin content of rice bran in roasting and microwave treatment significantly ( $\mathrm{P}$ $<0.05)$ increased $(125.73 \pm 1.10 \mathrm{mg}$ TAE$/ g$ of dry extract and $65.89 \pm 0.03 \mathrm{mg} \mathrm{TAE} / \mathrm{g}$ of dry extract respectively) compared to untreated. Total flavonoid content of rice bran samples in roasting and microwave treatment significantly $(\mathrm{P}<0.05)$ increased $(4.97 \pm 0.04 \mathrm{mg} \mathrm{QE} / \mathrm{g}$ of dry extract and $4.62 \pm 0.01$ $\mathrm{mg} \mathrm{QE} / \mathrm{g}$ of dry extract respectively) compared to untreated sample at $-20^{\circ} \mathrm{C}$ for 16 weeks. Total antioxidant activity of rice bran samples in roasting and microwave treatment significantly $(\mathrm{P}<0.05)$ increased $(123.80 \pm 0.55 \mathrm{mg} \mathrm{AAE} / \mathrm{g}$ of dry extract and $122.41 \pm 0.30 \mathrm{mg} \mathrm{AAE} / \mathrm{g}$ of dry extract respectively) compared to untreated sample at $-20^{\circ} \mathrm{C}$ for 16 weeks. The IC50 value indicates the dose of the sample which scavenges $50 \%$ of DPPH activity. Therefore, $6.01 \mathrm{mg} / \mathrm{ml}$ of rice bran is needed to scavenge $50 \%$ $\mathrm{DPPH}$ in case of untreated rice bran stored at $4^{\circ} \mathrm{C}$ for 16 weeks. The microwave treated sample has the lowest IC50 value $(3.49 \pm$ $0.04 \mathrm{mg} / \mathrm{ml}$ ). Data are showed in Table 3.

Table 3: Total Phenolic (mg GAE/g of dry extract), tannin (mg TAE/g of dry extract), flavonoid (mg QE/g of dry extract), antioxidant activity (mg AAE/g of dry extract) and IC50 (mg/ml) of different heat treatment sample compared to untreated rice bran preserved at $-20^{\circ} \mathrm{C}$ and $4{ }^{\circ} \mathrm{C} .{ }^{*} \mathrm{P}$ value $<0.05$ was considered statistically significant compared to untreated sample.

\begin{tabular}{|c|c|c|c|c|c|c|c|c|c|c|}
\hline \multirow[t]{2}{*}{ Parameters } & \multicolumn{2}{|c|}{ Untreated } & \multicolumn{2}{|c|}{ Autoclave } & \multicolumn{2}{|c|}{ Roasting } & \multicolumn{2}{|c|}{ Steaming } & \multicolumn{2}{|c|}{ Microwave } \\
\hline & $\begin{array}{c}\text { Preserved } \\
\text { at }-20\end{array}$ & $\begin{array}{l}\text { Stored } \\
\text { at } 4^{\circ} \mathrm{C}\end{array}$ & $\begin{array}{l}\text { Preserved } \\
\text { at }-20\end{array}$ & $\begin{array}{l}\text { Stored } \\
\text { at } 4^{\circ} \mathrm{C}\end{array}$ & $\begin{array}{l}\text { Preserved } \\
\text { at }-20\end{array}$ & $\begin{array}{l}\text { Stored } \\
\text { at } 4^{\circ} \mathrm{C}\end{array}$ & $\begin{array}{c}\text { Preserved } \\
\text { at }-20\end{array}$ & $\begin{array}{l}\text { Stored } \\
\text { at } 4^{\circ} \mathrm{C}\end{array}$ & $\begin{array}{c}\text { Preserved } \\
\text { at }-20\end{array}$ & $\begin{array}{l}\text { Stored } \\
\text { at } 4^{\circ} \mathrm{C}\end{array}$ \\
\hline Phenolic & $67.06 \pm 0.2$ & $31.74 \pm 0.5$ & $32.85 \pm 0.6^{*}$ & $41.71 \pm 0.3^{*}$ & $125.7 \pm 0.3^{*}$ & $37.23 \pm 1.4$ & $38.88 \pm 0.1^{*}$ & $28.21 \pm 1.2$ & $84.5 \pm 0.8^{*}$ & $32.59 \pm 0.2$ \\
\hline Tannin & $50.29 \pm 0.2$ & $24.78 \pm 0.1$ & $30.19 \pm 0.1^{*}$ & $28.87 \pm 1.1$ & $125.7 \pm 1.0^{*}$ & $26.62 \pm 0.6$ & $28.32 \pm 0.3^{*}$ & $19.99 \pm 0.9^{*}$ & $65.8 \pm 0.1^{*}$ & $23.31 \pm 0.3$ \\
\hline flavonoid & $2.60 \pm 0.3$ & $8.82 \pm 0.3$ & $2.03 \pm 0.1$ & $2.03 \pm 0.3^{*}$ & $4.9 \pm 0.1^{*}$ & $2.76 \pm 0.1^{*}$ & $1.73 \pm 0.1^{*}$ & $8.14 \pm 1.3$ & $4.6 \pm 0.0^{*}$ & $3.74 \pm 0.0^{*}$ \\
\hline Antioxidant & $83.60 \pm 0.1$ & $101.7 \pm 0.1$ & $60.06 \pm 0.1^{*}$ & $61.69 \pm 0.0^{*}$ & $123.8 \pm 0.5^{*}$ & $77.45 \pm 1.1^{*}$ & $27.21 \pm 0.8^{*}$ & $96.63 \pm 0.9$ & $122.4 \pm 0.3^{*}$ & $77.21 \pm 0.3$ \\
\hline IC50 (mg/ml) & $3.57 \pm 0.1$ & $6.01 \pm 1.1$ & $3.59 \pm 0.6$ & $3.69 \pm 0.7^{*}$ & $3.6 \pm 0.1$ & $4.09 \pm 0.1$ & $4.45 \pm 0.2^{*}$ & $4.79 \pm 0.1^{*}$ & $3.5 \pm 0.1$ & $3.54 \pm 0.1^{*}$ \\
\hline
\end{tabular}

\section{Oil extraction yield from rice bran samples with different heat treatment}

Percent of oil extraction were performed in four different heat treatments sample for one rice bran variety. The oils were extracted from untreated and treated samples by Soxhlet, as described in method section. The oil extraction range was $10.21 \%-22.34 \%$ in different groups. Figure 1 show that roasting and microwave heating were efficient to oil extraction yield compared to untreated sample. But, steam treated sample had least oil extraction yield. Data are showed in figure 1.

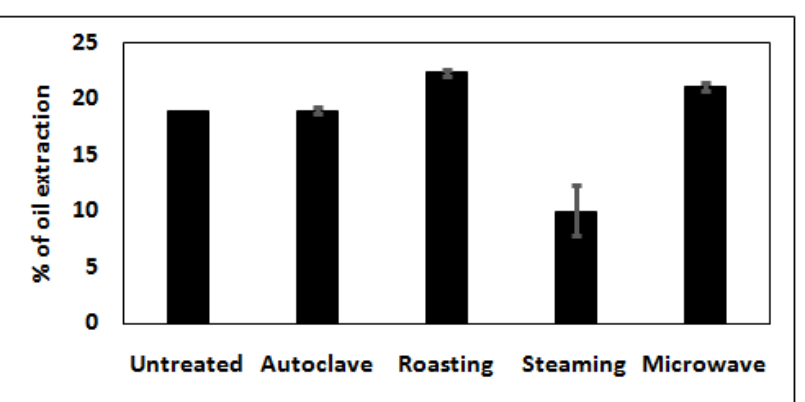

Figure 1: Oil extraction yield of rice bran samples with different treatments. The bar diagram is drawn from the mean value of the observations, and the error bar represents the SEM value. *P value $<0.05$ was considered statistically significant compared to untreated sample. 


\section{Effect of heat treatment on oxidative stability, peroxide value and acid value}

Oxidative stability assessed by the Rancimattest. The difference between the stability at $-20^{\circ} \mathrm{C}$ and $4^{\circ} \mathrm{C}$ for 16 weeks samples were significant irrespective of untreated and heat treatment. The untreated sample preserved at $-20^{\circ} \mathrm{C}$ had the highest induction time (11.22) compared to untreated preserved at $4^{\circ} \mathrm{C}(2.63)$ for 16 weeks. All the treated samples preserved at $-20^{\circ} \mathrm{C}$ showed significant differences with untreated sample. But preserved at $4^{\circ} \mathrm{C}$ for 16 weeks treated samples showed significant increased induction time compared to untreated samples except steaming treated samples. The roasting treatment significantly increased the induction time among the treatment groups.

Peroxide value and acid value of rice bran oil (extracted from untreated and treated sample) were analyzed by titration method. The acid value is significantly decreased in roasting and microwave treated sample compared to untreated sample preserved at both $-20^{\circ} \mathrm{C}$ and $4^{\circ} \mathrm{C}$ for 16 weeks. Whereas the peroxide value have a trend to lower in roasting and microwave treated sample compared to untreated sample preserved at $4{ }^{\circ} \mathrm{C}$ for 16 weeks. These values also showed a significant relationship with oxidative stability $(\mathrm{P}<0.001)$. It was found that when oxidative stability increases, the peroxide value and acid value decrease. Data are showed in Table 5 and 6.

\section{Effect of stability-indicating heat treatment on fatty acid composition of extracted rice bran oil}

The fatty acid composition (by Gas Chromatography) of extracted rice bran oil showed that the total saturated fatty acid ranged from $21.58 \%$ to $23.31 \%$, monounsaturated fatty acid ranged from $39.89 \%$ to $42.24 \%$ and polyunsaturated fatty acid ranged from $35.11 \%$ to $38.64 \%$. The heat treated sample preserved at $-20^{\circ} \mathrm{C}$ and $4^{\circ} \mathrm{C}$ for 16 weeks had changes in FFA level. The microwave and roasting treated samples showed slight increase of FFA compared to untreated sample. In heat treated roasting and microwave sample increased $(1.00 \%$ and $0.85 \%$ respectively) poly unsaturated fatty acid (PUFA) even though slightly decreased in mono unsaturated fatty acid (MUFA) preserved at $-20^{\circ} \mathrm{C}$ for 16 weeks. Data are showed in Table 4 .

\begin{tabular}{|c|c|c|c|c|c|c|c|c|c|c|}
\hline \multirow[b]{2}{*}{ Fatty Acids (\%) } & \multicolumn{2}{|c|}{ Untreated } & \multicolumn{2}{|c|}{ Autoclave } & \multicolumn{2}{|c|}{ Roasting } & \multicolumn{2}{|c|}{ Steam } & \multicolumn{2}{|c|}{ Microwave } \\
\hline & $\begin{array}{l}\text { Preserved } \\
\text { at }-20\end{array}$ & $\begin{array}{l}\text { Stored at } \\
\qquad 4^{\circ} \mathrm{C}\end{array}$ & $\begin{array}{l}\text { Preserved } \\
\text { at }-20\end{array}$ & $\begin{array}{l}\text { Stored at } \\
\quad 4^{\circ} \mathrm{C}\end{array}$ & $\begin{array}{l}\text { Preserved } \\
\text { at }-20\end{array}$ & $\begin{array}{l}\text { Stored at } \\
4^{\circ} \mathrm{C}\end{array}$ & $\begin{array}{c}\text { Preserved } \\
\text { at }-20\end{array}$ & $\begin{array}{l}\text { Stored at } \\
\qquad 4^{\circ} \mathrm{C}\end{array}$ & $\begin{array}{l}\text { Preserved } \\
\text { at }-20\end{array}$ & $\begin{array}{l}\text { Stored at } \\
\quad 4^{\circ} \mathrm{C}\end{array}$ \\
\hline Myristic Acid (C14:0) & 0.309 & 0.286 & 0.271 & 0.3 & 0.278 & 0.223 & 0.286 & 0.297 & 0.305 & 0.265 \\
\hline Palmitic Acid (C16:0) & 19.272 & 19.582 & 19.251 & 19.418 & 20.325 & 20.89 & 19.076 & 20.148 & 19.095 & 20.274 \\
\hline Stearic Acid (C18:0) & 1.356 & 1.352 & 1.288 & 1.352 & 1.376 & 1.44 & 1.392 & 1.415 & 1.416 & 1.441 \\
\hline Arachidic Acid (C20:0) & 0.428 & 0.605 & 0.578 & 0.486 & 0.582 & 0.427 & 0.6 & 0.632 & 0.629 & 0.647 \\
\hline Behenic Acid (C22:0) & ND & 0.203 & 0.146 & ND & ND & ND & ND & ND & ND & 0.313 \\
\hline Lignoceric Acid (C24:0) & 0.21 & 0.332 & 0.346 & 0.268 & 0.32 & 0.167 & 0.324 & 0.329 & 0.378 & 0.366 \\
\hline $\begin{array}{c}\text { Total Saturated Fatty } \\
\text { Acids }\end{array}$ & 21.575 & 22.361 & 21.879 & 21.825 & 22.881 & 23.149 & 21.679 & 22.822 & 21.82 & 23.306 \\
\hline Palmitoleic Acid (C16:1) & ND & ND & 0.091 & ND & ND & ND & ND & ND & ND & 0.093 \\
\hline Eicosenoic Acid (C20:1) & 0.215 & 0.329 & 0.33 & 0.273 & 0.341 & 0.207 & 0.347 & 0.325 & 0.342 & 0.354 \\
\hline Erucic Acid (C22:1) & ND & ND & ND & ND & ND & ND & ND & ND & ND & ND \\
\hline $\begin{array}{c}\text { Monounsaturated Fatty } \\
\text { Acids }\end{array}$ & 42.244 & 40.032 & 40.202 & 39.532 & 39.934 & 39.898 & 42.245 & 40.297 & 41.141 & 41.579 \\
\hline $\begin{array}{l}\text { Linoleic Acid (C18:2) } \\
\text { (Omega-6) }\end{array}$ & 35.147 & 36.418 & 36.697 & 37.479 & 36.053 & 35.86 & 35.063 & 35.742 & 35.92 & 34.067 \\
\hline $\begin{array}{l}\text { Linolenic Acid (C18:3) } \\
\text { (Omega-3) }\end{array}$ & 1.034 & 1.189 & 1.222 & 1.163 & 1.132 & 1.094 & 1.013 & 1.139 & 1.116 & 1.048 \\
\hline $\begin{array}{c}\text { Polyunsaturated Fatty } \\
\text { Acids }\end{array}$ & 36.181 & 37.607 & 37.919 & 38.643 & 37.185 & 36.953 & 36.076 & 36.88 & 37.034 & 35.115 \\
\hline $\begin{array}{c}\text { Total Unsaturated Fatty } \\
\text { Acids }\end{array}$ & 78.425 & 77.64 & 78.12 & 78.175 & 77.119 & 76.851 & 78.321 & 77.177 & 78.175 & 76.694 \\
\hline
\end{tabular}


Table 5: Oxidative stability assessed by the Rancimat test and the induction time of oils extracted from heat treated and untreated rice bran. Data is presented as mean \pm SEM. $*$ P value $<0.05$ was considered statistically significant compared to untreated sample.

\begin{tabular}{|c|c|c|}
\hline \multirow{2}{*}{ Sample treatment } & \multicolumn{2}{|c|}{ Induction time } \\
\cline { 2 - 3 } & Preserved at -20 & Stored at $4^{\circ} \mathrm{C}$ \\
\hline Untreated & $11.22 \pm 0.01$ & $2.63 \pm 0.07$ \\
\hline Autoclave treated & $7.75 \pm 0.07^{*}$ & $4.2 \pm 0.47^{*}$ \\
\hline Roasting & $8.48 \pm 0.56$ & $3.67 \pm 0.07^{*}$ \\
\hline Steam treated & $0.39 \pm 0.06^{*}$ & $0.34 \pm 0.08^{*}$ \\
\hline Microwave treated & $4.82 \pm 0.03^{*}$ & $4.37 \pm 0.02^{*}$ \\
\hline
\end{tabular}

Table 6.Peroxide (mg Eqv/ $\mathrm{kg}$ oil) and acid value ( $\mathrm{mg} \mathrm{KOH} / \mathrm{g}$ oil) of different heat treated rice bran samples compared to untreated sample. Data is presented as mean \pm SEM. ${ }^{*}$ P value $<0.05$ was considered statistically significant compared to untreated sample.

\begin{tabular}{|c|c|c|c|c|c|c|c|c|c|c|}
\hline \multirow{2}{*}{ Parameters } & \multicolumn{2}{|c|}{ Untreated } & \multicolumn{2}{c|}{ Autoclave } & \multicolumn{2}{c|}{ Roasting } & \multicolumn{2}{c|}{ Steam treated } & \multicolumn{2}{c|}{ Microwave } \\
\cline { 2 - 12 } & $\begin{array}{c}\text { Preserved } \\
\text { at }-20\end{array}$ & $\begin{array}{c}\text { Stored } \\
\text { at } 4^{\circ} \mathrm{C}\end{array}$ & $\begin{array}{c}\text { Preserved } \\
\text { at }-20\end{array}$ & $\begin{array}{c}\text { Stored } \\
\text { at } 4^{\circ} \mathrm{C}\end{array}$ & $\begin{array}{c}\text { Preserved } \\
\text { at }-20\end{array}$ & $\begin{array}{c}\text { Stored } \\
\text { at } 4^{\circ} \mathrm{C}\end{array}$ & $\begin{array}{c}\text { Preserved } \\
\text { at }-20\end{array}$ & $\begin{array}{c}\text { Stored at } \\
4^{\circ} \mathrm{C}\end{array}$ & $\begin{array}{c}\text { Preserved } \\
\text { at }-20\end{array}$ & $\begin{array}{c}\text { Stored at } \\
4^{\circ} \mathrm{C}\end{array}$ \\
\hline Peroxide & $4.8 \pm 0.7$ & $39.7 \pm 0.1^{*}$ & $6.2 \pm 1.3$ & $36.8 \pm 0.8^{*}$ & $8.8 \pm 0.3^{*}$ & $36.3 \pm 1.5$ & $8.3 \pm 0.4^{*}$ & $40.7 \pm 0.4$ & $6.9 \pm 0.5^{*}$ & $30.7 \pm 0.3^{*}$ \\
\hline Acid value & $16.1 \pm 0.1$ & $77.5 \pm 1.5^{*}$ & $10.2 \pm 0.1$ & $9.2 \pm 0.3^{*}$ & $7.6 \pm 0.0^{*}$ & $21.0 \pm 0.3^{*}$ & $21.2 \pm 0.0^{*}$ & $60.0 \pm 0.0^{*}$ & $8.7 \pm 0.0^{*}$ & $41.4^{*} 0.2^{*}$ \\
\hline
\end{tabular}

Effect of stability-indicating heat treatment on gamma oryzanol content of rice bran

Gama oryzanol content of rice bran samples was measured by HPLC method against gamma oryzanol standard. Gamma oryzanol content has four fractions that were identified in this study. The gamma oryzanol content ranged from $2.14 \mathrm{mg} / \mathrm{g}$ to $3.57 \mathrm{mg} / \mathrm{g}$ ). The heat treatment affects the Gamma oryzanol content. Untreated rice bran that was preserved at $-20^{\circ} \mathrm{C}$ and $4{ }^{\circ} \mathrm{C}$ for 16 weeks showed that only $0.1 \%$ reduced in 40C for 16 weeks. Among the heat treatment methods microwave, autoclave and roasting has high level of gamma oryzanol. Study on effect of heat stabilization of rice bran in various domestic methods, the range for gamma oryzanol content was from 2.03 to $2.30 \mathrm{~g} / 100 \mathrm{~g}$ oil. The gamma oryzanol content in this study for bran samples is ranged from $2.14-3.57 \mathrm{mg} / \mathrm{g}$ bran. The microwave heating retained more gamma oryzanol $(3.10 \pm 0.07 \mathrm{mg} / \mathrm{g})$ than the raw bran in our study. Data are showed in Table 7.

Table 7.Gamma oryzanol content of different heat treated rice bran samples compared to untreated. Gamma Oryzanol content is presented as Mean \pm Standard error of mean (SEM).** The ferulates are expressed as the percentages of gamma oryzanol and calculated on the basis of their area. ${ }^{*} \mathrm{P}$ value $<0.05$ was considered statistically significant compared to untreated sample.

\begin{tabular}{|c|c|c|c|c|c|c|c|c|c|c|}
\hline \multirow[t]{2}{*}{ Parameters } & \multicolumn{2}{|c|}{ Untreated } & \multicolumn{2}{|c|}{ Autoclave } & \multicolumn{2}{|c|}{ Roasting } & \multicolumn{2}{|c|}{ Steam treated } & \multicolumn{2}{|c|}{ Microwave } \\
\hline & $-20^{\circ} \mathrm{C}$ & $4^{\circ} \mathrm{C}$ & $-20^{\circ} \mathrm{C}$ & $4^{\circ} \mathrm{C}$ & $-20^{\circ} \mathrm{C}$ & $4^{\circ} \mathrm{C}$ & $-20^{\circ} \mathrm{C}$ & $4^{\circ} \mathrm{C}$ & $-20^{\circ} \mathrm{C}$ & $4^{\circ} \mathrm{C}$ \\
\hline $\begin{array}{c}\text { Gamma oryzanol content } \\
(\mathrm{mg} / \mathrm{ml})\end{array}$ & $3.3 \pm 0.1$ & $3.2 \pm 0.0$ & $2.2 \pm 0.0^{*}$ & $2.6 \pm 0.1$ & $3.5 \pm 0.1 *$ & $2.4 \pm 0.1$ & $3.2 \pm 0.1$ & $2.6 \pm 0.1$ & $3.1 \pm 0.1$ & $2.9 \pm 0.1^{*}$ \\
\hline Cycloartenylferulate ${ }^{* *}$ & $10 \%$ & $11 \%$ & $9 \%$ & $11 \%$ & $10 \%$ & $11 \%$ & $10 \%$ & $10 \%$ & $10 \%$ & $12 \%$ \\
\hline $\begin{array}{c}\text { 24-methylene } \\
\text { cycloartenylferulate }^{* *}\end{array}$ & $50 \%$ & $51 \%$ & $51 \%$ & $50 \%$ & $50 \%$ & $51 \%$ & $50 \%$ & $51 \%$ & $50 \%$ & $51 \%$ \\
\hline Campesterylferulate** & $28 \%$ & $26 \%$ & $29 \%$ & $26 \%$ & $29 \%$ & $26 \%$ & $28 \%$ & $27 \%$ & $28 \%$ & $25 \%$ \\
\hline$\beta$ - sitosterylferulate ${ }^{* *}$ & $12 \%$ & $11 \%$ & $10 \%$ & $13 \%$ & $11 \%$ & $12 \%$ & $12 \%$ & $12 \%$ & $11 \%$ & $12 \%$ \\
\hline
\end{tabular}

\section{Discussion}

In this study, we have used four different domestic heating methods to stabilize rice bran at $-20^{\circ} \mathrm{C}$ and $4^{\circ} \mathrm{C}$ for 16 weeks. We stored the bran for 16 weeks in zipper top bags. The proximate composition of rice bran samples were 1.69\%-12.25\% moisture, $13.91 \%-17.45 \%$ protein, $10.21 \%-22.34 \%$ fat, $6.59 \%-8.80 \%$ ash, $6.64 \%-13.69 \%$ crude fiber, $45.63 \%-54.86 \%$ carbohydrate. The heat treated samples had a good extraction yield such as roasting (22.34 $\pm 0.55 \mathrm{~g} / 100 \mathrm{~g}$ bran), microwave heating $(21.07 \pm 0.61)$ and autoclaving (18.98 \pm 0.55$)$, steaming (10.31 \pm 4.0 ) compared to the untreated rice bran $(18.97 \pm 0.06)$. The autoclave sample showed higher $(12.25 \pm 0.09 \%)$ moisture content than the untreated samples $(10.53 \pm 0.18 \%)$. But the roasting samples have lowest moisture content $(1.63 \pm 0.06 \%)(\mathrm{P}<0.05)$ due to higher heating level in roasting method. The moisture content has an inverse relation with extraction yield. That's why we could extracted more oils from roasting and microwave treatments. On the other hand, autoclaved and steamed samples showed higher 
moisture content, but lower extraction yield. The total phenolic, tannin, flavonoid and total antioxidant activity ranged 28.21$125.73 \mathrm{mg} \mathrm{GAE} / \mathrm{g}$ of dry extract, 19.99-125.72 mgTAE/g of dry extract, $1.73-8.82 \mathrm{mg} \mathrm{QE} / \mathrm{g}$ of dry extract and $27.21-123.80 \mathrm{mg}$ AAE/g of dry extract respectively. The DPPH radical scavenging activities are expressed as IC50 values and ranged 3.56- 6.01 $\mathrm{mg} / \mathrm{mL}$. In our study, the antioxidant values show significantly increased $(\mathrm{P}<0.05)$ in microwave and roasting methods because perfect heating time. The IC50 values for scavenging DPPH was lower in autoclaved samples whereas increased in microwave and roasting which indicates a good antioxidant activity. The level of antioxidants was reduced in some heat treatment group than the untreated samples, because some of the heat treatments caused reduction in the antioxidant levels. But the most important finding is that the reduction of antioxidants were significantly decreased in stability at $-20^{\circ} \mathrm{C}$ for 16 weeks of heat treated samples compared to stored at $4^{\circ} \mathrm{C}$ untreated sample. This stability indicating preservation showed that the reduction of their antioxidant level was slower than the untreated sample. So, most of the heat-treated of rice bran can have excellent free radical scavenging effect upon stability indicating storage. Our results corresponds to the previous studies that was found heat treatments can retain more antioxidants from plants [31-32].

Previous study found that the higher the induction time inhance the stability of rice bran [33-34]. In present research the range for the induction time is 0.37 hour to 11.22 hour. It was found that the induction time of heat stabilized (such as microwave treated, autoclaved and roasting sample ) rice bran samples preserved at $-20^{\circ} \mathrm{C}$ for 16 weeks declined in a certain scale of induction compared to the untreated bran sample, and steamed samples showed significantly $(\mathrm{P}<0.001)$ lower induction time. On the other hand, after 16 weeks of storage at $4^{0} \mathrm{C}$ for 16 weeks showed different phenomena. It was found that the induction time decreased drastically in case of untreated rice bran (11.22 \pm 0.01 hour to $2.63 \pm 0.07$ hour). Steamed samples also exhibited a lower induction period that indicates that it is not a suitable method for rice bran stabilization. But the microwave heated sample showed unchanged in 4 months compared to the untreated bran sample $(4.82 \pm 0.03$ hour to $4.37 \pm 0.02$ hour). Autoclaved sample had also lower change in induction time (7.75 \pm 0.07 hour to $4.23 \pm 0.02$ ). Induction time of roasting sample ( $8.48 \pm 0.56$ hour to $3.67 \pm 0.07$ hour) also indicate improved stability than untreated sample. Though the heat stabilized samples exhibited lower induction time but it was found that after storage of 4 months the change is very lower from the untreated rice bran.

Total free fatty acid in stored untreated rice bran sample was decreased. But the stored heat treated rice bran samples have very little change in free fatty acid level in comparison to the stored untreated rice bran, free fatty acid of microwave-treated sample increased $2.76 \%$, autoclaved and roasted samples were almost unchanged. On the other hand, FFA of stored steamed sample increased significantly $5.52 \%$. The treated rice bran samples that were not stored also had change in FFA level. Microwave treated, autoclave and steamed samples showed increase of FFA compared to untreated sample. But roasting sample showed $0.28 \%$ decrease in FFA level. In this study, the fatty acid composition of extracted rice bran oil shows that total saturated fatty acid ranged from $21.58-23.31 \%$, monounsaturated fatty acid $39.89-42.24 \%$ and polyunsaturated fatty acid $35.11-38.64 \%$. All treated sample, specially stored roasting and microwave heated sample retained a significantly high level of polyunsaturated fatty acid compared to stored untreated polyunsaturated fatty acid (PUFA) level. Moreover, stored autoclaved sample has decreased level of monounsaturated fatty acids (MUFA). Here, the essential fatty acid (EFA) levels of rice bran were changed in a beneficial way upon storage.

The range for peroxide value of heat treated preserved samples at $-20^{\circ} \mathrm{C}$ for 16 weeks were 4.81 to $8.34 \mathrm{mg}$ Eqv $/ \mathrm{kg}$ oil whereas the samples stored at $4^{\circ} \mathrm{C}$ were 30.70 to $40.69 \mathrm{mg}$ Eqv $/ \mathrm{kg}$ oil in our study. The increase in peroxide value is due to the time lag of preservation at $4^{\circ} \mathrm{C}$. Here, all heat treated stabilized rice bran sample showed lower peroxide value than the unstabilisedbran except steamed sample. These results correspond to the result for stability measurement by induction time. However, the range for acid value of sample that preserved at $-20^{\circ} \mathrm{C}$ for 16 weeks were 7.57 to $21.22 \mathrm{mg} \mathrm{KOH} / \mathrm{g}$ oil. Here, steamed sample showed higher value $(21.22 \pm 0.005 \mathrm{mg} \mathrm{KOH} / \mathrm{g})$ due to the difference of the sample preparation process. The acid value range of rice bran sample that preserved at $40 \mathrm{C}$ were 9.22 to $77.46 \mathrm{mg} \mathrm{KOH} / \mathrm{g}$ oil. The acid value has increased due to the time gap of 4 months preservation at 4 0C. But the stored autoclaved sample $(9.22+$ $0.31 \mathrm{mg} \mathrm{KOH} / \mathrm{g})$, and roasting sample $(21.06+0.31 \mathrm{mg} \mathrm{KOH} / \mathrm{g})$ showed a much less acid value than the untreated stored (77.46 \pm $1.58 \mathrm{mg} \mathrm{KOH} / \mathrm{g}$ ) bran oil. These results correspond to the result of free fatty acid level in this study.

The gamma oryzanol content in our study for bransamples is ranged from 2.19-3.63 mg/g bran. Gamma-oryzanols analogues were identified as ferulic acid esters of cycloartenyl, 24-methylene cycloartanyl, campesteryl and $\beta$-sitosterol. The individual components cycloartenyl, 24-methylene cycloartenyl and campesteryl are the three major components which account for $80 \%$ of oryzanols. The gamma oryzanols fraction of rice bran sample were cycloartenyl ferulate (9-12\%), 24-methylene cycloartenyl ferulate (50-51\%), campesteryl ferulate $(25-29 \%)$, $\beta$-sitosteryl ferulate $(10-13 \%)$.Total gamma oryzanols content of microwave and roasting that were preserved at $-20^{\circ} \mathrm{C}$ for 16 weeks were found highest level compare to preserved at $4^{\circ} \mathrm{C}$ untreated sample. The microwave and roasting retained more gamma oryzanol $(3.53 \pm 0.07 \mathrm{mg} / \mathrm{g})$ than the untreated bran in our study.

\section{Conclusions}

This result demonstrated that roasting and microwaves heat treatment would be effective method for stability-indicating stabilization of rice bran food value. The functional composition and oil recovery was significant than the untreated rice bran and also other heat treatment. The oil quality especially with 
respect to its storability is better for the roasting and microwave treated samples for 16 weeks compared to untreated samples. Moreover, microwave and roasting being a one-step simple, dry, time manageable and energy efficient processing operation reduces the energy requirement and other associated food science problems. Finally the findings of the current study will help to stabilize rice bran for longer period of time impeding the faster reduction of its nutrient and antioxidant properties. Implementation of appropriate stabilization methods for rice bran food value may accrue over and above its properties. Thus roasting and microwave heating methods would be better for rice bran food value stabilization than other heating steaming and autoclave.

\section{References}

1. Bangladesh Bureau of Statistics, M. O. P., Government of Bangladesh, Dhaka (1999). Year Book of Agricultural Statistics. BBS.

2. MA Zubair, MS Rahman, MS Islam, MZ Abedin and MA Sikder. A Comparative Study of The Proximate Composition of Selected Rice Varieties in Tangail, Bangladesh J. Environ. Sci. \& Natural Resources. 2015;8(2):97-102.

3. M Lutfor Rahman, N Absar, MD Ibrahim H Mondal, MK Hossan, Seatara Khatun and GRM Astak Mohal Khan. Lipid, fatty acid and glyceride composition of five different varieties of rice bran oil. Bangladesh research publications journal. 2013;9(2):111-115.

4. Tunce NB, Yllmaz N. Gamma-oryzanol content, phenolic acid profiles and antioxidant activity of rice milling fractions. European Food Research and Technology. 2011;233(4):577-585.

5. Mohammed A Satter, HA Sajabin, N Abedin, AK Azad, Abul Hossain and $U$ Ara. Nutritional Composition and Stabilization of Local Variety Rice Bran BRRI-28. International Journal of Science and Technology. 2014;3(5):306-313.

6. Hamada J. Characterization and functional properties of rice bran proteins modified by commercial exoproteases and endoproteases. Journal of Food Science. 2000;65(2):305-310.

7. Champagne ET, Hron RJ, Abraham G. Utilizing ethanol to produce stabilized brown rice products. Journal of the American Oil Chemists' Society. 1992;69(3):205-208.

8. Tao J, Rao R, Liuzzo J. Microwave heating for rice bran stabilization. Journal of microwave power and electromagnetic energy. 1993; 28(3):156-164.

9. Sharma HR, Chauhan GS, Agrawal K. Physico-chemical characteristics of rice bran processed by dry heating and extrusion cooking. International Journal of Food Properties. 2004;7(3):603-614.

10. Laning SJ. Fats, oil, fatty acids, and oil seed crops. Biotechnology and Food Ingredients. 1991;265-313.

11. Zigoneanu I, Williams L, Xu Z, Sabliov C. Determination of antioxidant components in rice bran oil extracted by microwave-assisted method. Bioresource Technology. 2008;99(11):4910-4918.

12. Juliano BO. Rice properties and processing. Food Reviews International. 1985;1(3):423-445.

13. Zhu W, Yao H. Visual studies on rice bran extrusion. Knowledge Enterprise: Intelligent Strategies in Product Design, Manufacturing, and Management. 2006;966-971.
14. Amarasinghe B, Kumarasiri M, Gangodavilage N. Effect of method of stabilization on aqueous extraction of rice bran oil. Food and Bioproducts Processing. 2009;87(2):108-114.

15. Sharmila S, Kar A, Mohapatra D. Stabilization of rice bran using microwave: Process optimization and storage studies. Food and Bioproducts Processing. 2006;99:204-211.

16. Nordin NNAM, Karim R, Ghazali HM, Adzahan, NM, Sultan M. Effects of various stabilization technique son the nutritional quality and antioxidant potential of brewer's rice. J. Eng. Sci. Technol. 2014;9:347363.

17. Ramezanzadeh FM, Rao RM, Windhauser M, Prinyawiwatkul W, Marshal WE. Prevention of oxidative rancidity in rice bran during storage. J. Agric. Food Chem. 1999;47(8):2997-3000.

18. Zigoneanu I, Williams L, Xu Z, Sabliov C. Determination of antioxidant components in rice bran oil extracted by microwave-assisted method. Bioresource Technology. 2008;99(11):4910-4918.

19. Horwitz W. Official methods of analysis (Vol. 222). Washington, DC: Association of Official Analytical Chemists. 1975.

20. Hamid F, FH Hamid. manual of methods of analysis of foods. oils and fats test by Farhang Hamid. 2016.

21. Kahlon TS. Rice bran: production, composition, functionality and food applications, and physiological benefits, CRC Press, Taylor \& Francis Group: Boca Raton, FL, USA. 2009.

22. Ainsworth EA and Gillespie KM. Estimation of total phenolic content and other oxidation substrates in plant tissues using Folin-Ciocalteu reagent. Nature protocols. 2007;2(4):875-877.

23. Zhishen J, Mengcheng T. and Jianming W. The determination of flavonoid contents in mulberry and their scavenging effects on superoxide radicals. Food chemistry. 1999;64(4):555-559.

24. Prieto P, Pineda M, Aguilar M. Spectrophotometric quantitation of antioxidant capacity through the formation of a phosphomolybdenum complex: specific application to the determination of vitamin E. Analytical biochemistry. 1999;269(2):337-341.

25. Frankel EN, Meyer AS. The problems of using one-dimensional methods to evaluate multifunctional food and biological antioxidants. Journal of the Science of Food and Agriculture. 2000;80(13):19251941.

26. Gomes de Melo J, de Sousa Araújo TA, Thijan Nobre de Almeida e Castro V, Lyra de Vasconcelos Cabral D, Do Desterro Rodrigues M, Carneiro do Nascimento S, Cavalcanti de Amorim EL, et al. Antiproliferative activity, antioxidant capacity and tannin content in plants of semi-arid northeastern Brazil. Molecules. 2010;15(12):8534-8542.

27. American Oil Chemists' Society, 1990. Official methods and recommended practices of the American Oil Chemists' Society. AOCSPr.

28. Gordon MH, Mursi E. A comparison of oil stability based on the

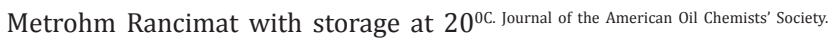
1994;71(6):649-651.

29. Oluremi OI, Solomon AO, Saheed AA. Fatty acids, metal composition and physico-chemical parameters of Igbemo Ekiti rice bran oil. Journal of Environmental Chemistry and Ecotoxicology. 2013;5(3):39-46.

30. Tuncel NB, Yllmaz N. Gamma-oryzanol content, phenolic acid profiles and antioxidant activity of rice milling fractions. European Food Research and Technology. 2011;233(4):577-585. 
31. Jeong SM, SY Kim, DR. Kim, SC Jo, K Nam, D Ahn et al. Effect of heat treatment on the antioxidant activity of extracts from citrus peels. Journal of agricultural and food chemistry. 2004;52(11):3389-3393.

32. Lee SC, JH Kim, SM Jeong, DR Kim, JU Ha, K Nam et al. Effect of farinfrared radiation on the antioxidant activity of rice hulls." Journal of agricultural and food chemistry. 2003;51(15):4400-4403.
33. Rosniyana A, Hashifah MA, Shariffah Norin SA. Nutritional content and storage stability of stabilised rice bran-MR 220. Journal of Tropical Agriculture and Food Science. 2009;37(2):163-170.

34. Anwar F, Bhanger M, Kazi T. Relationship between rancimat and active oxygen method values at varying temperatures for several oils and fats. Journal of the American Oil Chemists' Society. 2003;80(2):151155. 